\title{
An evaluation of low voltage counterimmuno- electrophoresis for the detection of hepatitis-B antigen (HB Ag)
}

\author{
E. O. CAUL AND P. C. ROBERTS \\ From the Public Health Laboratory, Myrtle Road, Kingsdown, Bristol
}

SYNOPSIS A newly available low voltage counterimmunoelectrophoresis (CIEP) system for the $\mathcal{N}$ detection of $\mathrm{HB} \mathrm{Ag}$ (Hapindex, Ortho Diagnostics) was compared with a conventional CIEP $\overrightarrow{\mathrm{N}}$ method used at this laboratory. A total of 1216 sera were tested. The Hapindex system was found to be at least as sensitive as the conventional CIEP. No false positives were found in this series. The elimination of any preparative work makes the Hapindex system particularly suitable for laboratories not testing large numbers of sera for HB Ag. It also eliminates many of the contamination hazards inherent in the conventional method.

At the present time many methods are available for the detection of $\mathrm{HB} \mathrm{Ag}$. These include simple double diffusion (Blumberg, Alter, and Visnich, 1965), latex agglutination tests (Leach and Ruck, 1971), and the more commonly used or more complex tests such as haemagglutination (Reesink, Duimel, and Brummelhuis, 1973), counterimmunoelectrophoresis (CIEP) (Gocke and Howe, 1970), complement fixation (Shulman and Barker, 1969), immune electron microscopy (Almeida, Zuckerman, Taylor, and Waterson, 1969; Bayer, Blumberg, and Werner, 1968; Dane, Cameron, and Briggs, 1970), and radioimmunoassay (Prince, Brotman, Jass, and Ikram, 1973). Apart from the simple double-diffusion, latex agglutination, and the haemagglutination tests the remaining techniques require expensive equipment and/or technical expertise. It is generally accepted that of these, radioimmunoassay is the most sensitive test (Cossart, Boxall, and Flewett, 1973). The remaining methods vary in their sensitivity, the least and most sensitive being the double-diffusion and haemagglutination tests respectively.

Ortho Diagnostics have introduced a low voltage CIEP system (Hapindex) which because of its simplicity enables the routine pathological laboratories to carry out their own $\mathrm{HB} \mathrm{Ag}$ screening tests. This paper describes and evaluates the Hapindex system in comparison with that of a conventional CIEP for the detection of HB Ag.

Received for publication 10 September 1974.

\section{Materials}

Between 1970 and 1973, 1216 sera were tested by conventional counterimmunoelectrophoresis metho used at this laboratory. All sera were subsequently stored at $-30^{\circ} \mathrm{C}$ before testing by the Hapindex system. Of these sera, 41 were to be used as 'quality control' sera in a biochemistry laboratory. The remaining 1175 sera originated from the normal population and from patients with a variety of clinical diseases. These were divided into the following categories:

\section{CATEGORY 1}

Sera from blood donors were received from the National Blood Transfusion Service. These were not the normal blood donor population but were suspected on laboratory or epidemiological grounds of either carrying HB Ag or having HB antibody (HB Ab).

\section{CATEGORY 2}

Hospital staff.

CATEGORY 3

People with a past history of hepatitis, transplant donors, mothers of babies with cirrhosis, and children whose mothers had hepatitis.

\section{CATEGORY 4}

Patients with acute or chronic hepatitis, renal 
failure, polyarteritis, leukaemia, Hodgkin's disease, and haemophilia.

\section{CATEGORY 5}

Pools of human sera which were to be used as 'quality control' sera in a biochemistry laboratory.

\section{Low Voltage (17 Volt) Counterimmunoelectro- phoresis (Hapindex)}

The system consists of a cassette containing buffered agar with pre-cut rectangular wells and indwelling electrodes, a power unit and a separate viewer with a monochromatic light source. After the addition of the sera to the appropriate wells the cassette is plugged into the power unit and the current switched on. The power unit automatically switches off after one hour, this being indicated by the appearance of a light. The cassette is removed and examined in the viewer for lines of precipitation.

Twelve sera can be examined for HB Ag in each cassette including a known positive control. The $\mathrm{HB} \mathrm{Ab}$ provided with the system is raised against 'ad' and 'ay' subtypes of $\mathrm{HB} \mathrm{Ag}$ by Ortho Diagnostics and standardized to detect weak and strong concentrations of $\mathrm{HB} \mathrm{Ag}$ in test sera. This system has been described elsewhere (McKee, Pollack, and Tripodi, 1973).

\section{Conventional Counterimmunoelectrophoresis}

The method of Milne and Barr (1971) with square

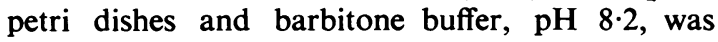
modified.

\section{HB ANTIBODY}

The various batches of antibody used during this period (1970-1973) originated from human and animal sources. Working dilutions, previously standardized by titration, were stored at $4^{\circ} \mathrm{C}$.

\section{HB ANTIGEN (POSITIVE CONTROL)}

Working dilutions were stored at $4^{\circ} \mathrm{C}$. The dilution for use was obtained by titration against the $\mathrm{HB} \mathrm{Ab}$ in current use.

\section{TEST}

Wells were cut in the agarose on the day of the test using a no. 1 cork borer $(3.5 \mathrm{~mm}$ diameter) and a blood transfusion needle ( $2 \mathrm{~mm}$ diameter), using a template to give a distance of $5 \mathrm{~mm}$ between antibody and antigen wells. Each test serum was placed in one $2 \mathrm{~mm}$ and one $3.5 \mathrm{~mm}$ well and tested against two $2 \mathrm{~mm}$ antibody wells. This system was designed so that high and low concentrations of $\mathrm{HB} \mathrm{Ag}$ could be detected in test sera.
Test sera and antibody were placed in their respective wells, filter wicks were introduced $(100 \mathrm{~mm} \times 80 \mathrm{~mm})$ and the plate was placed in the electrophoresis tank. The current was switched on, adjusted to 30 milliamps, and the apparatus was left for 75 minutes. At the end of this time the plate was removed and examined for lines of precipitation using a bright indirect light source with a black background. Results were recorded and the agarose was then flooded with normal saline and left at room temperature overnight. The following day the plate was re-examined for any additional lines of precipitation which may have developed.

\section{Immune Electron Microscopy}

Test serum $(0.2 \mathrm{ml})$ was added to $0.1 \mathrm{ml}$ of $\mathrm{HB} \mathrm{Ab}$ (previously standardized by chessboard titration) and left at room temperature for $\mathbf{3 0}$ minutes. The mixtures were then centrifuged at $49000 \mathrm{~g}$ in the SM 24 rotor of a Sorvall RC2-B centrifuge for 75 minutes. After discarding the supernatant, the deposit was resuspended in one drop of glassdistilled water. A formvar-coated 400 mesh Athene grid was inoculated with the deposit, and, after washing in glass-distilled water, stained with $1.5 \%$ $(\mathrm{w} / \mathrm{v})$ sodium phosphotungstate, $\mathrm{pH} 6 \cdot 5$. Grids were examined in an AEI 801 electron microscope at a magnification of $\times 40000$ for 15 minutes before they were considered negative. A known positive serum containing $\mathrm{HB} \mathrm{Ag}$ was included in each batch of tests.

\section{Results}

A total of 1216 sera were tested by the Hapindex and conventional CIEP methods (see table). Of these, 133 sera were positive by Hapindex whereas 131 were positive by CIEP. Thus Hapindex detected two additional HB Ag-positive sera. Both of these were confirmed by immune electron microscopy. Immune electron microscopy was also carried out on all the sera in 'category 5' and $\mathrm{HB} \mathrm{Ag}$ was detected in 2/41 sera; neither were detected by the two counterimmunoelectrophoresis systems used.

QUALITY CONTROL

In order to determine the reproducibility of the Hapindex system, two HB Ag-positive sera were tested against three different batches of $\mathrm{HB} A \mathrm{Ab}$ in six different batches of cassettes. One of the HB Agpositive sera was known to give a very weak precipitation line whilst the second serum gave a strong prozone reaction. There was no variation between the different batches of cassettes or antibodies in the 
type of precipitation lines produced by the two antigens.

\section{Discussion}

The Hapindex low-voltage counterimmunoelectrophoresis is a simple test requiring little technical expertise. It has certain advantages over the conventional CIEP in that the cassette is ready for use and requires no preparative work. We found the system completely reliable during the course of this evaluation. The use of monochromatic light in the viewer was considered to be particularly good for the recognition of very weak precipitation lines. This was impressively demonstrated when lines of precipitation were examined on the two systems by totally inexperienced staff who found the Hapindex monochromatic light system superior.

Using this system, contamination of the operator is reduced to a minimum by removing the necessity of handling possibly contaminated wicks and buffer. Also the cassette is provided with a lid which is kept in place after the reagents have been added and during the test period. When the test has been completed the entire cassette is disposable. The use of low voltage also reduces the risk to the operator.

The detection of two additional positive sera by Hapindex (see table) may have been due to greater

\begin{tabular}{lccccc}
\hline Category & $\begin{array}{l}\text { Total Sera } \\
\text { Tested }\end{array}$ & \multicolumn{2}{l}{ Hapindex } & & \multicolumn{2}{c}{ CIEP } \\
\cline { 3 - 6 } & & - & - & & - \\
\hline 1 & 183 & 77 & 106 & 77 & 106 \\
2 & 136 & 4 & 132 & 4 & 132 \\
3 & 96 & 4 & 92 & 4 & 92 \\
4 & 760 & $48^{1}$ & 712 & 46 & 714 \\
5 & $41^{2}$ & 0 & 41 & 0 & 41 \\
Total & 1216 & 133 & 1083 & 131 & 1085 \\
\hline
\end{tabular}

Table Comparative results obtained by Hapindex and conventional CIEP

${ }^{1}$ The two additional positives detected by Hapindex were confirmed by electron microscopy.

2Two of these sera were positive by electron microscopy.

sensitivity of the Hapindex system, which uses a broad-spectrum antibody and is balanced to detect both weak and strong concentrations of antigen (McKee et al, 1973). A further possibility is that this system uses rectangular rather than the conventional circular wells. This possibly results in a higher concentration of antigen at the point of precipitation. The antibodies used in the conventional test originated from either a human or animal source and did not have a broad spectrum. The Hapindex system has also been found to be more sensitive than the conventional CIEP by other workers (McKee et al, 1973) but it is unlikely to be as sensitive as haemagglutination or radioimmunoassay.
Two sera were positive for HB Ag by immune electron microscopy (see table) but were not detected by the two systems described here. These were pools of human sera, so that any $\mathrm{HB} \mathrm{Ag}$ present in one serum would be diluted by the other sera in the pool. Thus the two CIEP systems described were not sufficiently sensitive to detect the low concentration of antigen present.

On no occasion did we obtain a false positive result using the Hapindex system. This is an advantage over the latex agglutination test (Leach and Ruck, 1971; Cossart, Field, March, and Porter, 1972; Klossner and Willman, 1973) and some haemagglutination tests (Reesink et al, 1973).

We considered that Hapindex suffered from the disadvantage of having only sufficient wells to test 12 sera (including one positive control) on each cassette as compared with 100 tests on our conventional counterimmunoelectrophoresis.

Although we think that Hapindex is not suitable 을 for mass screening of sera for $\mathrm{HB} \mathrm{Ag}$ it is an ideal $\rightarrow$ system for smaller laboratories which receive relatively few requests for $\mathrm{HB} \mathrm{Ag}$ detection. It may $\mathbb{\AA}$ also be useful to biochemistry departments for $\overline{3}$ screening sera before autoanalysis and to laboratories involved in venereal disease serology.

We wish to acknowledge Ortho Diagnostics fo supplying the Hapindex system with which this wor was carried out. We are indebted to Dr S. K. R? Clarke for her advice and criticism in the preparation of this paper.

\section{References}

Almeida, J. D., Zuckerman, A. J., Taylor, P. E., and Waterson, A. P. (1969). Immune electron microscopy of the Australia SH (serum hepatitis) antigen. Microbios, 2, 117-123.

Bayer, M. E., Blumberg, B. S., and Werner, B. (1968). Particles associated with Australia antigen in the sera of patients with leukaemia, Down's syndrome and hepatitis. Nature (Lond.), 218, 1057-1059.

Blumberg, B. S., Alter, H. J., and Visnich, S. (1965). A 'new' antigen in leukemia sera. J. Amer. med. Ass., 191, 541-546.

Cossart, Y. E., Boxall, E., and Flewett, T. H. (1973). False-negative radioimmunoassay tests for $\mathrm{Au}$ antigen. Lancet, 2, 1333-1334.

Cossart, Y. E., Field, A. M., March, S. P., and Porter, A. A. (1972) Latex test for Australia antigen. Lancet, 2, 379.

Dane, D. S., Cameron, C. H., and Briggs, M. (1970). Virus-like particles in serum of patients with Australia-antigen-associated hepatitis. Lancet, 1, 695-698.

Gocke, D. J., and Howe, C. (1970). Rapid detection of Australia antigen by counterimmunoelectrophoresis. J. immunol., 104, S $1031-1032$.

Klossner, M., and Willman, K. (1973). Latex test, complement fixation and immunoelectroosmophoresis in detection of $\omega$ Australia antigen. Lancet, 1, 322-323.

Leach, J. M., and Ruck, B. J. (1971). Detection of hepatitis associated antigen by the latex agglutination test. Brit. med. J., 4, 597-598. Co

McKee, A. P., Pollack, W., and Tripodi, D. (1973). Low voltage counterimmunoelectrophoresis for the detection of Australia antigen. Vox. Sang. (Basel), Suppl., 24, 80-83.

Milne, G. R., and Barr, A. (1971). A rapid method for testing blood for hepatitis associated antigen and antibody using countercurrent-electrophoresis (immunoelectroosmophoresis) agarose gel. Sterilin Technical Bulletin, No. 1. 
Prince, A. M., Brotman, B., Jass, D., and Ikram, H. (1973). Specificity of the direct solid-phase radioimmunoassay for detection of hepatitis-B antigen. Lancet, 1, 1346-1350.

Reesink, H. W., Duimel, W. J., and Brummelhuis, H. G. J. (1973).
Evaluation of a new haemagglutination technique for the demonstration of hepatitis-B antigen. Lancet, 2, 1351-1353.

Shulman, N. R., and Barker, L. F. (1969). Virus-like antigen, antibody. and antigen-antibody complexes in hepatitis measured by complement fixation. Science, 165, 304-306.

\section{Reports and Bulletins prepared by the Association of Clinical Biochemists}

The following reports and bulletins are published by the Association of Clinical Biochemists. They may be obtained from The Publishing Department, British Medical Journal (ACB Technical Bulletins), B.M.A. House, Tavistock Square, London WC1H 9JR. Overseas readers should remit by British Postal or Money Order.

SCIENTIFIC REPORTS (price $£ 1 \cdot 00 / \$ 2.00$ each)

3 Automatic Dispensing Pipettes: an assessment of 35 commercial instruments September 1967 P. M. G. BROUGHTON, A. H. GOWENLOCK, G. M. WIDDOWSON, and K. A. AHLQUIST

4 An Evaluation of five Commercial Flame Photometers suitable for the Simultaneous Determination of Sodium and Potassium March 1970 P. M. G. BROUGHTON and J. B. DAWSON

\section{SCIENTIFIC REVIEWS (price $£ 1 \cdot 00 / \$ 2.00$ each)}

1 The Assessment of Thyroid Function March 1971 F. V. FLYNN and J. R. HOBBS

2 Renal Function Tests Suitable for Clinical Practice January 1972 F. L. MITCHELL, N. VEALL, and R. W. E. WATTS

TECHNICAL BULletiNs (price $f 1.00 / \$ 2.00$ each)

9 Determination of Urea by AutoAnalyzer November 1966 RUTH M. HASLAM

11 Determination of Serum Albumin by AutoAnalyzer using Bromocresol Green October 1967 B. E. NORTHAM and G. M. WIDDOWSON

13 An Assessment of the Technicon Type II Sampler Unit March 1968 B. C. GRAY and G. K. McGowAN

14 Atomic Absorption Spectroscopy: an outline of its principles and a guide to the selection of instruments May 1968 J. B. DAWSON and P. M. G. BROUGHTON

15 A Guide to Automatic Pipettes (2nd edition) June 1968 P. M. G. BROUGHTON

16 A Guide to Automation in Clinical Chemistry May 1969 P. M. G. BROUGHTON

17 Flame Photometers: a comparative list of 17 instruments readily available in Britain August 1969 P WILDING

19 Spectrophotometers: a comparative list of low-priced instruments readily available in Britain May 1970 C. E. WILDE and P. SEWELL
20 Quantities and Units in Clinical Biochemistry June 1970 P. M. G. BROUGHTON

21 Filter Fluorimeters: A comparative list of 18 instruments September 1970 H. BRAUNSBERG and S. S. BROWN

22 Bilirubin Standards and the Determination of Bilirubin by Manual and Technicon AutoAnalyzer Methods January 1971 BARBARA BILLING, RUTH HASLAM, and N. WALD

23 Interchangeable Cells for Spectrophotometers and Fluorimeters September 1971 S. S. BROWN and A. H. GOWENLOCK

24 Simple Tests to Detect Poisons March 1972 B. w. MEADE et al.

25 Blood Gas Analysers May 1972 K. DixoN

26 Kits for Enzyme Activity Determination September 1972 S. B. ROSALKI and D. TARLOW

27 Assessment of Pumps Suitable for Incorporation into Existing Continuous Flow Analytical Systems November 1972 A FLECK et al.

28 Routine Clinical Measurements of Transferrin in Human Serum September 1973 K. DIXON

29 Control Materials for Clinical Biochemistry (5th edition) September 1973 J. F. STEVENS

30 Notes on the Quality of Performance of Serum Cholesterol Assays September 1973 s. S. BROWN

31 Determination of Uric Acid in Blood and in Urine July 1974 R. W. E. WATTS

32 A Survey of Amino Acid Analyzers Readily Available in the United Kingdom September 1974 J. E. CARLYLE and P. PURKISS.

33 Definitions of some Words and Terms used in Automated Analysis November 1974 A. FLECK, R. ROBINSON, S. S. BROW'N, and J. R. HOBBS. 